\title{
Problems of Arabic Language Teaching in Traditional Institutes (An Experimental Study at Miftah Al-Huda Institute 2 as a Model)
}

\author{
Lina Marlina ${ }^{1}$, Arif Ramdani ${ }^{2}$ \\ ${ }^{1}$ Universitas Islam Negeri Sunan Gunung Djati, Indonesia \\ ${ }^{2}$ Universitas Halim Sanusi Bandung, Indonesia \\ Correspondence: lina7671@gmail.com; arif7176@gmail.com
}

\begin{abstract}
Some traditional Islamic boarding schools in Indonesia in teaching Arabic only focus on teaching the rules of language, memorizing vocabularies with their meanings, without regarding the importance of speaking, listening, reading, and writing skills, and the development of Arabic teaching curriculum that is relevant for non-native Arabic students. The main problem in teaching Arabic in traditional boarding schools is reflected in the understanding of learning objectives, teaching materials, teaching methods, and the quality of teachers. The aim of this paper is to describe the basic concepts of learning Arabic for non-native Arabic students. The main solution to overcome the problem of teaching Arabic is to set learning goals that are in line with the needs analysis, create teaching materials suitable for learning Arabic for non-Arabic natives, use effective teaching methods, and select teachers who are trained and have a good competency in teaching language.
\end{abstract}

Keywords: traditional Islamic boarding schools; teaching problems; main solutions 